

\section{THE CARBON AGE}

The amount of carbon dioxide that humans have pumped into the atmosphere so far pales in comparison to the volume that would be produced if all remaining reserves were burned.

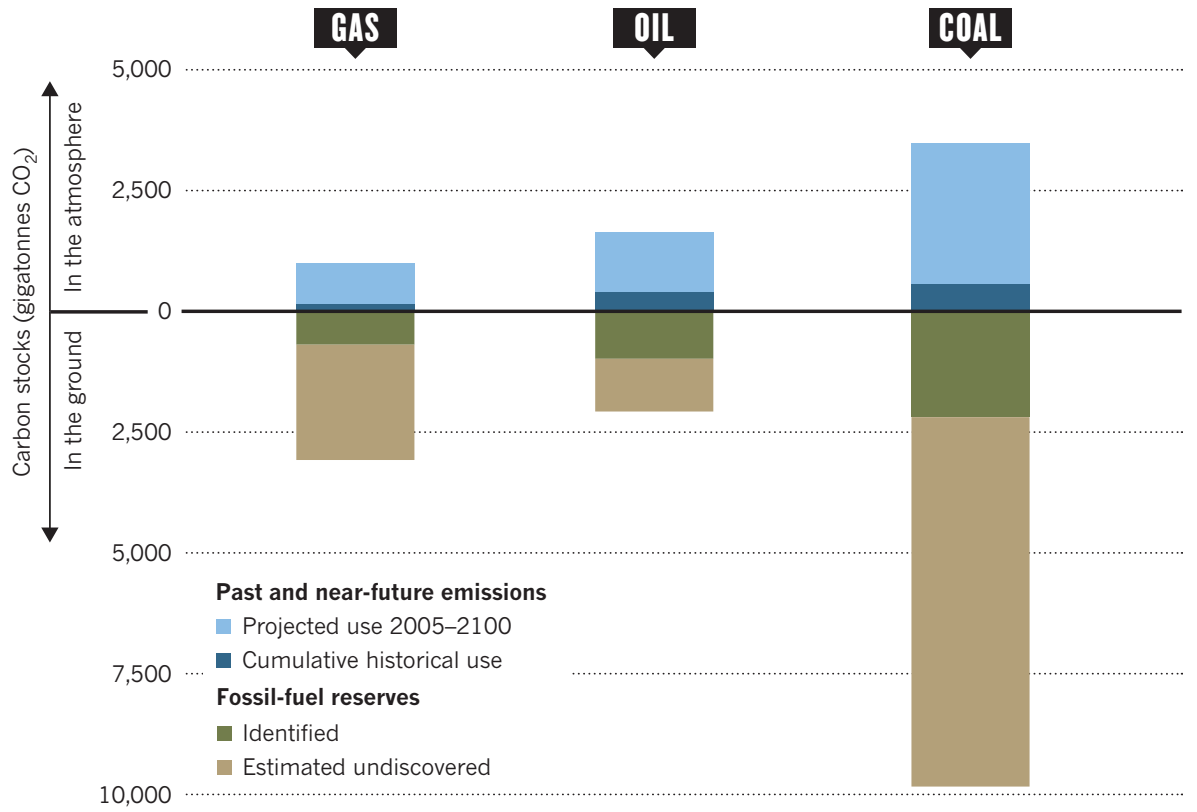

$\checkmark$ every single sentence in the summary of a report on renewable energies.

"It's an emotional roller coaster," says Edenhofer, chief economist at the Potsdam Institute for Climate Impact Research in Germany. "Things can get pretty nasty when delegations play their little games of power, and the chairs must be prepared to parry attacks. My little reminder to always stay cool and polite has saved me from fits more than once."

His temper will be tested again during the coming months as he guides his committee the IPCC's Working Group III, which looks at ways to mitigate climate change - towards the end of its five-year reporting process. A week-long meeting in late June and early July in Addis Ababa turned into a marathon for the 232 lead authors of the report, who were faced with addressing more than $16,000 \mathrm{com}$ ments submitted by expert reviewers and governments in response to an early draft. Next month, Edenhofer's committee must send a revised version to governments to prepare for April 2014, when lead authors and government representatives will meet in Berlin to hammer out the final report.

\section{BLUEPRINTS FOR A GREEN FUTURE}

Edenhofer will need to marshall a unique blend of skills, honed during a stint as a Jesuit philosophy scholar and through research on game-theory, as he completes the most sweeping compendium yet of technology and policy options that might spare humanity from the worst of climate change in the coming decades.

The report will lay out a range of scenarios — and the costs and risks of each - for transforming societies to stabilize greenhouse-gas concentrations at reasonably safe levels.
The results will inform the political process through a round of global climate negotiations intended to culminate in a treaty in 2015 . And as nations continue to disagree over the architecture and ambitions of that pact, the IPCC's take on mitigation will come under heavy scrutiny. The IPCC is charged only with laying out the science - and, in the past, critics have accused the group's leaders of overstepping the boundary between analysing research and advocating for action.

Well aware of that risk, Edenhofer has strived to keep his group focused on a strictly scholarly agenda - and, in so doing, he has won over some of the IPCC's past critics.

\section{"THIN NASTYWHEN DELEEATIONS PLAY THERRLITTLE GAMES OF POWER."}

"Ottmar has amazing skills," says Robert Stavins, an environmental economist at Harvard University in Cambridge, Massachusetts, who did not work on the last IPCC report out of concerns that it had grown too political. "I can't think of anybody better fitted for the job."

Philosophy was Edenhofer's intellectual refuge early on. Hailing from an

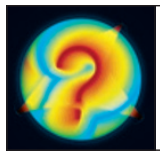
OUTLOOK FOR EARTH A Nature special issue on the IPCC nature.com/ipcc2013 arch-conservative part of Bavaria in south Germany, he shocked his parents - and prompted the local book seller to declare him crazy when he spent his savings at the age of 14 on the three volumes of Das Kapital by Karl Marx. Reading the German philosopher's critique of the capitalist mode of production didn't turn him into an ardent Marxist, but did spark his interest in political economics. A couple of years later, the writings of German sociologist Max Weber prompted him to ponder the value of science and the difficult relationship between values and facts - problems that are right at the core of any serious debate on the role of the IPCC.

In the mid-1980s, Edenhofer studied economics at the University of Munich, Germany, but his academic career soon took an unusual detour. In 1987, he joined the Jesuit order in Munich to immerse himself in Western philosophy and, later, in theology. Soaking up the works of Weber, Ludwig Wittgenstein and John Dewey, he learned to embrace different lines of reasoning. In 1991, he also became involved in setting up a Jesuit Refugee Service in Bosnia and Croatia during the Yugoslav Wars, and later earned a $\mathrm{PhD}$ in economics at the Technical University of Darmstadt, Germany.

His roots in philosophy are still palpable in the way that he approaches the climate conundrum."There is a whole space of morally legitimate standpoints with a view to climate change," he says one day in May, while sipping coffee between sessions of a workshop on climate agreements in Berlin. His boyish face, framed by round spectacles, grows animated as he lays out the various perspectives. "One might legitimately argue that the fight against global warming is as morally imperative as abolishing child labour or slavery. One might argue - just as legitimately — that poverty and diseases in many parts of the world are more imminent problems that should be addressed first."

However, he adds, some perspectives cannot be tolerated. "Denying out-and-out that climate change is a problem to humanity, as some cynics do, is an unethical, unacceptable position.'

The upcoming Working Group III report that Edenhofer is presiding over is a massive, complex tome. A compendium of hundreds of scientific papers, it analyses how societies can slow down climate change and reduce its effects by altering all sectors of the economy, from electricity production to transportation to building design. The importance of his group's work has grown as the greenhouse problem has worsened with no political solution in sight. Since the 2007 IPCC report, emissions of heat-trapping gases have continued to grow despite a global economic recession. In 2012, annual emissions of such gases were equivalent to more than 50 billion tonnes of carbon dioxide and reached an all-time high. And, in May 2013, the concentration of atmospheric $\mathrm{CO}_{2}$ 
crossed the ominous threshold of 400 parts per million (p.p.m.) for the first time since human beings appeared on Earth.

The report will provide a range of scenarios, and cost estimates, for stabilizing atmospheric $\mathrm{CO}_{2}$ concentrations at 450 or 550 p.p.m.. It will make it clear that all realistic stabilization scenarios are decidedly at odds with current emissions trends. In fact, if one factors in methane, nitrous oxide and other warming gases that are governed by the 1997 Kyoto Protocol climate treaty, the combined concentration has already surpassed the equivalent of 450 p.p.m. of $\mathrm{CO}_{2}$. As a result, stabilization plans must allow for nations to temporarily overshoot a target before concentrations might start to subside.

The report will also make clear that the problem will only grow worse without action. Known hydrocarbon reserves still buried in the ground may contain up to four times as much carbon as has been released into the atmosphere since the onset of the Industrial Revolution (see 'The carbon age').

But in line with the IPCC's mandate which requires the group to be policy-neutral - the assessment of Working Group III will avoid promoting certain mitigation options over others. Maintaining that distance will be a crucial test of Edenhofer's leadership.

"The IPCC is a scientific body whose task is to compare and review the relevant literature," says Stavins. "Unfortunately, in my view, the IPCC has in the past overstretched its mandate. It has become too political - and that hasn't done it and the field any good." Stavins feels, for example, that prominent IPCC members transgressed by lobbying for green policies such as emission cuts and carbon taxes.

Edenhofer is keen to steer clear of such territory: he often compares the task of the IPCC to that of map-makers rather than to that of political advisers. But he also knows that the report, by necessity, will weigh in on politically charged issues such as nuclear power, biofuels and geoengineering. When the report's summary for policy-makers - its most-read and most-disputed section - goes up for debate in April, the fighting among diplomats and scientists will be even tougher than it was in past sessions. Together with his Cuban and Malian co-chairs, Edenhofer will have to see, as patiently as his nature allows, that the haggling over the tiniest words proceeds in a civilized and productive manner.

He faces the date - his last as an IPCC official — with a mixture of anxiety and gladiatorial anticipation. "Where I grew up, the boys were always ready for a fight," he says. "I'm not like that - but trust me, I do know when it's time to thump on the table."

The stakes are mounting on his group's report. With its analyses of low-carbon energy options and different policy paths towards stabilizing greenhouse-gas concentrations, the report will be an important contributor to the upcoming negotiations as nations try to hammer out an international treaty over the next year.

When the last round of IPCC Assessment Reports came out in 2007, the body came under fire for including a few claims that lacked strong scientific support; in one high-profile gaffe, Working Group II uncritically repeated a baseless assertion that Himalayan glaciers would disappear by 2035. Edenhofer has pushed his own working group to thoroughly overhaul its procedures for evaluating scholarship to avoid such embarrassing blunders in his report. In particular, he has reduced the use of 'grey' literature - information not subjected to peer review, such as reports from environmental groups, governments and companies - to a minimum.

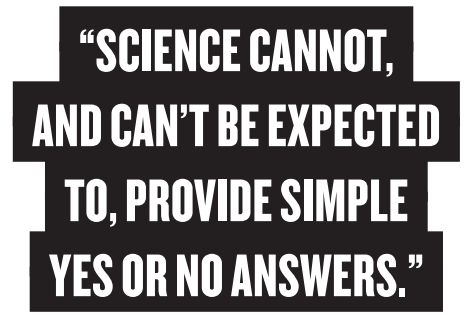

And, perhaps drawing on his background as a philosopher and theologian, Edenhofer has also broadened the scope of the IPCC's mitigation working group to give ethical considerations greater weight. For the first time, professional philosophers have been invited to contribute to the report's opening chapters on equality, risks and sustainability issues, which set the scene for more technical sections.

But even as it details the various options that nations might take, the report will not take sides, he stresses - because that involves decisions based on values and priorities that fall to elected officials. "Science cannot, and can't be expected to, provide simple yes or no answers," he says.

To tread that neutral line, Edenhofer will have to control his own strong opinions, formed during his years as an economist and climate-policy expert. He favours cap-andtrade schemes, for example, over a direct carbon tax as the most effective way to cut emissions and promote climate-friendly innovation. And he is adamant that the global transformation to a low-carbon economy cannot be achieved - no matter what goals key emitters might commit themselves to - without substantially increasing the use of renewable energy in all sectors of the economy.

In spite of his own opinions, he has focused on delivering an unassailable product. "Ottmar is keen to get the best science for the next IPCC report, which he wants to lift to a new level of quality," says Massimo Tavoni, deputy coordinator of climate-change programmes at the Eni Enrico Mattei Foundation in Milan, Italy.

Edenhofer is also ready to acknowledge the limits of knowledge in his field. The most important uncertainty, he says, concerns the reliability of economic models used to forecast the future. They rely on macroeconomic equations and assumptions that are often thwarted by real-world developments. Economists are well aware that although the models can anticipate broad trends, they have no ability to forecast disruptions such as major financial or political crises.

And great uncertainty remains over how nations will tackle climate change. How much will countries cooperate? To what degree will they rely on nuclear power? How quickly will renewable energy be deployed and at what price? Beyond those near-term concerns, researchers must also grapple with more distant potential mitigation strategies such as capturing and storing carbon on a massive scale, or large geoengineering projects aimed at rapidly staving off warming.

As Working Group III tackles such uncertainties, it will also wade into an increasingly contentious debate about the benefits of creating biofuels from plants and bacteria. Since the IPCC's 2007 report, a fast-growing body of literature has split over whether the indirect effects of growing crops for fuels do more harm than good to the climate.

Fears that excessive bioenergy production might cause food shortages make the debate even fiercer. "Clearly," says Edenhofer, "this is one of the most controversial issues we're dealing with. By now, debate over bioenergy has outstripped controversy over nuclear energy.' The IPCC, he says, will summarize the pros and cons as authoritatively as scientific knowledge allows.

\section{TEARY FINALE}

Edenhofer is convinced that the IPCC is better placed than any other group to address such thorny issues, because the final reports are vetted not only by scientists but also by political appointees from member nations. No purely science-led exercise could possibly have equal weight, he says. Although some scientists have started to question the utility of the IPCC, especially its drawn-out procedures, Edenhofer says the process should continue. The "miracle" of the IPCC, as he puts it, is that it forces governments to deal seriously with science.

"To be able to engage and criticize our work, governments do need to carefully read our reports," he says. "Here's a unique mechanism for bringing science to the very level of government leaders."

As he steers his group through that process, he will make frequent use of his desktop index card. But he has faith in the process. "When everything is said and done, and when even the most hard-boiled negotiators have tears in their eyes, it is the cause of science - and not power interests - that has the last word."

Quirin Schiermeier is a reporter for Nature in Munich, Germany. 